doi: $10.19090 /$ i.2018.29.92-109

ISTRAŽIVANJA

JOURNAL OF HISTORICAL RESEARCHES

29 (2018)
ORIGINAL SCIENTIFIC PAPER

Received: 4 May 2018

Accepted: 22 July 2018

\author{
JANKO RAMAČ \\ DANIELA MARČOK \\ University of Novi Sad, Faculty of Philosophy \\ Department of Ruthenian Studies, Department of Slovak Studies \\ janko.ramac@ff.uns.ac.rs \\ danielamarcokova@ff.uns.ac.rs
}

\title{
THE SETTLEMENT OF SLOVAKS IN KYSÁČ*
}

\begin{abstract}
The first Slovak colonists arrived in some villages of the landed estate of Futog around the middle of the fourth decade of the 18th century. The first Slovak evangelists came to Kysác in 1773. Our research focuses on the beginning and on the first decades of the arrival of Slovaks to this settlement. The aim of the research is to understand the beginnings and the basic social and economic circumstances at the time of the arrival of Slovaks in Kysác from the 7th decade of the 18th century to the beginning of the 19th century using authentic data, primarily from František Jesenský's Chronicle of the Evangelical Church in Kysáč (1773) and the data from the Archive of Vojvodina, which have been rarely used in previous research, as well as the registers from the archives of the Evangelical churches in Bášsky Petrovec and Kysáč and the existing written documents.

Keywords: "Lower Land", settlement of Slovaks in Bačka, landed estate of Futog, Kysáč, Evangelists.
\end{abstract}

\section{Written Documents on the Arrival of the Slovaks at the Lower Land}

The work of Ján Sirácky ${ }^{1}$ represents the basis of modern historiography of Slovaks on the Lower Land. ${ }^{2}$ Before him, some Slovak priests and teachers, historians, ethnographers and local chroniclers, such as Félix Kutlík, ${ }^{3}$ Jozef Maliak, ${ }^{4}$ Karol Lilge $^{5}$ and others tried to shed light on the history of Slovaks of Vojvodina. It was mainly

\footnotetext{
* The paper was completed as part of the following projects: Discourses of national minorities' languages, literatures and cultures in the South-east and Central Europe (178017), and Region of Vojvodina in context of european history (177002), both financed by the Ministry of education, science and technology of the Republic of Serbia.

${ }^{1}$ Lower Land is a historical term relating to the district of Southern Hungary up to 1918, modern day Vojvodina, part of Hungary and Romania, where the Slovaks live.

${ }^{2}$ Sirácky 1963a; Id. 1963b ; Id.1966a; Id.1966b; Id. 1974; Id. 1980; Id.1983; Id. 1985; Id. 2002.

${ }^{3}$ Kutlík 1887; Id. 1888; Id. 1981.

${ }^{4}$ Maliak 1889; Id. 1908; Id. 1921; Id. 1925; Id. 1939.

${ }^{5}$ Lilge 1932.
} 
publicistic work published in Slovak cultural and religious publications and journals. In the $20^{\text {th }}$ century and in recent times many people wrote about the past of Slovaks on the Lower Land: Ján Ormis, ${ }^{6}$ Andrej Mráz, ${ }^{7}$ Ján Botík, ${ }^{8}$ Samuel Čelovský, ${ }^{9}$ Samuel Jovankovič, ${ }^{10}$ Miroslav Kmet', ${ }^{11}$ Ján Jančovic, ${ }^{12}$ Ján Babiak, ${ }^{13}$ Jaroslav Miklovic ${ }^{14}$ and others.

A lot of articles, studies and collections of papers on the arrival of Slovaks and their life on the Lower Land were presented at different meetings and scholarly conferences and later published in various collections, some of them in professional journals. ${ }^{15}$ There were a few monographs and publications of professional literature on the national, regional, cultural and religious history of Slovaks of Vojvodina. ${ }^{16}$ In some of them articles were published on various aspects of the history of Kysác. ${ }^{17}$ In addition, on the occasion of the anniversaries of the establishment of Slovak settlements in Vojvodina, independent publications came out. ${ }^{18}$ One of such publications was a collection of studies and articles Kysáč 1773-2013, ${ }^{19}$ in which Janko Ramač ${ }^{20}$ has an article on the older past of Kysáč, and Samuel Čelovský ${ }^{21}$, Ján Babiak ${ }^{22}$ and Jaroslav Miklovic ${ }^{23}$ write about the arrival of Slovaks in Kysáč. There are also manuscripts of local chroniclers, former school principals, teachers and amateurs who in their own archives keep valuable documents, photographs and notes which are primarily related to the $20^{\text {th }}$ century.

The basic source on the settlement of Slovaks in Kysáč is a manuscript chronicle of František Jesenský Pamätnica historických zápisov, staršich a novšich, o povstaní a d'alšom zvel'ad'ovaní cirkvi, počnúc od r. 1773 (henceforth Pamätnica). ${ }^{24}$ Jesenský was the second Evangelical priest in Kysáč who served there from 1794-1805. He made the census in which he listed the names of the "heads" of families, the county and the village from which they came to Kysác and the year of their arrival. This chronicle was the basic source of research

\footnotetext{
${ }^{6}$ Ormis 1935.

${ }^{7}$ Mráz 1948; Id. 2004

${ }^{8}$ Botík 1980; Id. 1988; Id. 1994; Id. 1999; Id. 2007; Id. 2008; Id. 2009; Id. 2011.

${ }^{9}$ Čelovský 1980a; Id. 1980b; Id. 1980c; Id. 1982; Id. 1996; Id. 2010.

${ }^{10}$ Jovankovič 2014.

${ }^{11}$ Kmet' 2006; Id. 2008; Id. 2010a; Id. 2010b; Id. 2012.

12 Jančovic 2003; Id. 2004; Id. 2009.

${ }^{13}$ Babiak 2002; Id. 2015.

${ }^{14}$ Miklovic 2002; Id. 2006.

${ }^{15}$ Ambruš, Hlásnik 2013; Čáni 2001; Dudok 1996; Kmet' 1981; Krajčovič 1994-1997; Ormis 1946; Šišmiš 1995; Kolény 1892; Seberíny 1906; Id. 1907; Tomanová - Makanová (ed.) 2014.

${ }^{16}$ Auerhan 1921; Bielik, Sirácky, Baláž, (ed.) 1984; Čaplovič 1928; Vereš (ed.) 1930; Kmet’ 1994; Svetoň 1943.

${ }^{17}$ Babiak, 2015a: 289-310; Čelovský, 2010b: 326-348; Id. 2010c: 442-457; Turčan 1930.

${ }^{18}$ Bartoš 2001; Benková 1998; Boldocký (ed.) 1995; Bukurov, Chrt’an 1979; Cicka 2002; Čukan (ed.) 2010; Id. 2011; Id. 2013; Id. 2014; Fekete a kol. 1986; Id. 1998; Gašparovský 1998; Hučoková-Klinková 2005; Kišgeci (ed.) 1997; Kotváš 1996; Listmajer 2010; Matúch (ed.) 2008; Petráš 1996; Stupavský 2010; Turčan 1972; Valentík (ed.) 2008.

${ }^{19}$ Valentík (ed.) 2013

${ }^{20}$ Ramač 2013: 28-41.

${ }^{21}$ Čelovský 2013: 41-52.

${ }^{22}$ Babiak 2013: 52-66.

${ }^{23}$ Miklovic 2013: 66-72.

${ }^{24}$ Pamätnica can be found in the Archives of the Evangelical a.c. Chruch in Kysác. It was written in the Latin language, whereas some parts were written in the German and Slovak languages. Further details can be found in the works of S. Čelovský (2013: 44) and J. Babiak (2013: 59).
} 
of numerous authors who wrote on the past of Kysáč. In a short overview in a "booklet," as he calls it, Félix Kutlík was the first Slovak at the end of the $19^{\text {th }}$ century to publish basic information on Slovaks in Kysác ${ }^{25}$. At the beginning of the $20^{\text {th }}$ century Jozef Maliak analyzes Pamätnica more sistematically and publishes more detailed information from it. ${ }^{26}$ Since the above mentioned census of F. Jesenský appeared twenty years after the arrival of the first settlers, some of them were not alive at that time or they moved elsewhere so the information on the arrival the Slovaks in Kysác had to be completed with the data from the urbarial records and from saved registers. Unfortunately, no register books were found for the period from 1773-1783 when Slovaks in Kysáč belonged to the Roman Catholic parish in Novi Futog. From 1783-1788 Slovaks from Kysáč belonged to the Evangelical Church in Petrovec (today Báčsky Petrovec) and in that period they were registered in the books of the baptized, married, and deceased. After the arrival of the first evangelical priest Michal Slamay in Kysáč, from 1 January 1787, the register books of the faithful were regularly kept in that church. No records of canonical visitations of the evangelical parish in Kysác from the end of the $18^{\text {th }}$ and the beginning of the $19^{\text {th }}$ centuries, which probably contain very significant data on the arrival and life of Slovaks in this settlement in the first decades after the arrival, have been found to date.

\section{The Arrival of Slovaks in Kysáč}

In the historiography of Slovaks on the Lower Land authors mostly agree that the arrival of Slovaks to Kysáč started in 1773, which at the time was the place with predominantly Serbian population belonging to the landed estate of Futog. ${ }^{27}$ As a populated place, Kysác was mentioned for the first time around the middle of the $15^{\text {th }}$ century: in 1461 under the name Alch (Alcs), in 1464 - as Kys Alcz, and later in 1457 and in 1504 as Nagalcs. ${ }^{28}$ As a populated place Kysáč was also mentioned in Turkish defters in 1553. After that, it was not mentioned for a while. Therefore, Samuel Borovský (Samuel Borovszky) believes that the settlement had been destroyed. ${ }^{29}$ In the Hungarian censuses from 1715 and 1720 Kysáč was not mentioned. ${ }^{30}$

\footnotetext{
${ }^{25}$ Kutlík 1998: 60-61.

${ }^{26}$ Maliak 1925: 41-50.

${ }^{27}$ According to J. Babiak, the feudal estate of Futog spanned 24000 acres of land. The district administration was located in Futog to which, besides Kysáč, belonged also Petrovec, Hložany, Rumenka i Kamendin. Around 1703 , Baron Jozef Nehem took over this feudal estate from the military administration in Bačka. Further owners were constantly shifting. In 1721 it was Count Buterur, and in 1726 the estate was taken over by the Royal Chamber. A year later (1727), it comes to the hands of Jozef Odvajer, in 1731 its owner was Count Fridrih Cauvriani (Babiak 2013:53). Serbian family Čarnojević got this Chamber property for rent in 1740, during the reign of Maria Theresa (1740-80). The Čarnojevićs turned with a reques to the counties of Turoc, Hont, Novohrad and Pest to send them Slovak working families (Maliak 1921: 113). In 1745 farmers from Slovakia came to their estates in Petrovec (Sirácky 1980:66). In 1771 the estate was given to Count Field Marshal of the Austrian Army Andreas Hadik (1710-1790). According to Z. Đere, Count Hadik is known for perfecting the economy of Southern Bačka, building a church, a school, and a castle in Futog, and for his contribution in settling the Germans and Slovaks on the "Lower Land" (2014: 229)

${ }^{28}$ Csánki 1894: 142.

${ }^{29}$ Borovszky 1909: 96

${ }^{30}$ Jakšić 1966: Kysáč as a populated place is not mentioned in the two censuses, and its closest populated places were Alpar and Piroš (Rumenka). In 1715 there were 4, and in 1720 - 9 households in Alpar; in 1715 Piroš is
} 
Živan Sečanski states that "after the expulsion of the Turks" Kysáč was abandoned and that the new settlement was founded in $1758 .{ }^{31}$ Isidor Nikolić states that in 1722 there were 110 houses of Orthodox Serbs and an Orthodox church, but S. Borovszky considers this to be unreliable information and says that the landowners of Futog settled down in Kysáč not before the middle of the $18^{\text {th }}$ century. ${ }^{32}$ From that time it was practically possible to follow the massive arrival to Kysáč. During the urbarial regulation in 1770, by answering nine questions (Ad novem puncta urbarialia examinis et responsa possessionis Kisacs...), the inhabitants of Kysác stated that they had arrived to that settlement about fifteen years before and that they had signed the first contract with the landowners Jovan, Simeon and Pavle Čarnojević/Crnojević. ${ }^{33}$ The inhabitants of Kysáč, 19 native Serbs, signed a contract with Arsenije Čarnojević as the owner of the landed estate of Futog on 17 November 1758. The contract states that in the period from 1757-1760 they were exempted from all taxes and that beginning with 1760 they would pay annually 400 forints as a census/rent in two installments - the first one had to be paid by Pentecost, the second one by Mitrovdan (St. Demetrius, on 26 October according to the Julian Calendar, i.e. 8 November according to the Gregorian Calendar). Until the seventh decade of the $18^{\text {th }}$ century and the beginning of the arrival of Slovaks to this settlement, arable land occupied a small area of the Kysáč district, significantly smaller than the area of arable land in the neighbouring settlements Petrovec and Kulpín. ${ }^{34}$

In the above-mentioned answers to nine questions benefits and disadvantages for the inhabitants of Kysáč were stated. The benefits were: arable land was fertile, but it could not be tilled with two oxen; it took two hours to reach the Royal free city of Novi Sad by carriage, where the peasants/farmers could sell their products; there was enough water for the cattle in the district; on the other bank of the Danube were the vineyards of Srem, where they could work as day labourers and earn their money; in Futog, near the Danube, there were watermills; in search for work they went to Novi Sad as carriers from where they transported merchants as far as Budapest. The disadvantages for the inhabitants of Kysáč were as follows: there were few pastures so the cattle grazed in the fallows; there was no wood nor reed in the district; arable land was annually distributed to the peasants in such a way that the "best farmer" would get 25 acres, and the "smallest farmer" 3 acres; ${ }^{35}$ as far as meadows were concerned, the "best farmer" would get 20 scythes, and the "smallest one" 5 scythes; ${ }^{36}$ two thirds of the land were estimated as fertile and one third as medium fertile; for the purposes of his manor each farmer ploughed three days annually without being paid, worked during the harvest and transported the crops; one seventh of the crops was given to the landowner; they had the right of free moving. ${ }^{37}$ The mansion fiscal submitted later his comments on the urbarial census in nine points and on the circumstances in the municipality of Kysáć. ${ }^{38}$

\footnotetext{
not mentioned, and in 1720 there were 13 households in it.

${ }^{31}$ Sečanski 1952: 108.

${ }^{32}$ Borovszky 1909: 96-99.

${ }^{33}$ Ramač, 2010: 145.

${ }^{34}$ Look at the historical map First Military Survey (1763-1787). Available at: http://mapire.eu/en/

${ }^{35}$ Hungarian acre spanned in average 1200 square feet, the first class land 1100 square fathom.

${ }^{36}$ The surface a mower can mow in a day, which in average was 400 square fathom.

${ }^{37}$ Ramač, 2010: 146

${ }^{38}$ The Archives of Vojvodina, Novi Sad, Bač-Bodrog County (abbrev. AV BBŽ) no. 361-372/1772.
} 
At the beginning of the seventh decade of the $18^{\text {th }}$ century, the number of the inhabitants of Kysáč significantly rose: according to the Urbarial Census of Kysáč in 1772, a year before the arrival of the first Slovaks there were 107 households in the village, mostly Serbs. The nationality of the inhabitants is not mentioned and on the basis of the written form of their names it can not be ascertained with accuracy whether these were Serbian, Hungarian, Romanian or Slovak names. ${ }^{39}$

According to the Urbarial Income List of the chamber feudal ground estates of Futog from 1772 (Conscriptio et aestimatio Cameralis Dominii Futak), the landed estate received 400 forints from the municipality of Kysáč that year in the name of census/land rent. The manual work annuity of the subjects was 1248 days, counting the day by $112 / 3$ kreuzers, this obligation was 145 forints and 60 kreuzers a year. Two inns were obliged to pay a total of 356 forints annually. The owner of a shop paid an annual fee of 12 forints. Besides that, the subjects gave 1/7 of their crops, which made for the year: 564 p.m. (Peace of Pressburg) of wheat, i.e. 376 forints; 720 p.m. of barley -48 forints; 247 p.m. of oats -74 forints and 10 kreuzers; 287 p.m. of corn - 95 forints and 66 2/3 kreuzers; 104 p.m. of millet -34 forints and $662 / 3$ kreuzers; 16 bee hives -16 forints; 140 lambs -70 forints. The total was 1628 forints and $31 / 3$ kreuzers. ${ }^{40}$

In addition, the subjects also paid the county surtax and contribution - a state tax for the maintenance of the army. The contribution was paid in money or in kind. Very often military authorities disposed a number of soldiers into counties for the winter of for summer camping, the counties further disposed them to settlements, and in the settlements they were distributed for overnight stay to households. This obligation was a heavy burden, because the subjects had to provide a lot for the full maintenance of this army - for the officers, soldiers and military horses and to put up with all kinds of their offenses. Besides, the state determined maximum prices of all the produce that were regularly lower than the real prices on the market, to the subjects' disadvantage.

According to the Theresian Urbar from 1767 that was introduced in Bačka in 1772, the peasants, apart from other duties, had an obligation of the so called long rides, which meant the transportation of various goods for the needs of a feudal lord. In 1798 the landowners of Futog signed with the inhabitants of Kysáč a purchase contract of long rides for the price of 5 forints for a ride, which for the annually anticipated 24 2/16 rides made 120 forints and $372 / 4$ kreuzers, of which the subjects paid the first half by 24 April and the second by 29 September. ${ }^{41}$

In the Topographic Lexicon of Hungary from 1773 stays that the inhabitants of Kysác mainly used the Vlach, i.e. Romanian language - lingua vlachica and that in the village there was an Orthodox (schizmaticus) priest and a teacher. ${ }^{42}$ In this source, as well as in other documents on the history of Kysáč, it was explicitly stated that in the second half of the $18^{\text {th }}$ century Romanians, too, lived in the village. However, judging by the forms of names and surnames from the known censuses and other documents of that time it is evident

\footnotetext{
${ }^{39}$ OL, E szekció 156 - a. - Fasc. 158. - No. 024.

${ }^{40}$ OL, E szekció 156 - a. - Fasc. 188. - No. 025.

${ }^{41}$ AV BBŽ April 16, 1798, the village prince was Serb Gaja, and the jurors were two Serbs and two Slovaks.

${ }^{42}$ Lexicon locorum Regni Hungariae...1773: 24
} 
that the vast majority of the population were Serbs, and only few of them could be assumed to be the Romanians. ${ }^{43}$

The list of the believers of the Greek Catholic parish in Novi Sad from 1802 shows that there were six Greek Catholics in Futog and according to the lists of the believers of that parish from the first decades of the $19^{\text {th }}$ century, there were Greek Catholics in Kysáč, too: in 1810 there were 5 of them, and in 18259 Greek Catholics, i.e. Ruthenians. ${ }^{44}$ After that, in all likelihood, there were no more Ruthenians in Kysáč.

The literature on the very beginning of the arrival of Slovaks in Kysáč highlights the role of Count Andras/Andrej Hadik who, probably being of Slovak origin, wanted to bring to his estate in Futog as many compatriots as possible. ${ }^{45}$ Due to the lack of the original material, insufficiently precise interpretation of some sources and a vivid imagination of some authors, there were some doubts or insufficiently founded claims concerning this historical issue. Therefore, we will pay more attention to this issue.

In the historiography of Slovaks on the Lower Land it is widely accepted that the arrival of Slovaks in Kysáč started in 1773, but there is some dilemma about who came first. František Jesenský in his Pamätnica (chronicle) of Kysáč from 1794 says that first to arrive in Kysáč was the father of the then inhabitant of the village Duro Vardžík, but he does not cite his name. ${ }^{46}$ Jozef Maliak says that the first Slovak to settle in Kysáč was Ďuro Vardžík from Pilís ${ }^{47}$ and although he cites the aforementioned Chronicle by F. Jesenský, he obviously did not read his text carefully enough. Later, some other authors also used that information from J. Maliak. ${ }^{48}$ It is true that on the list of the believers of the Evangelical Church in Kysáč, during the canonical visitation on 15 September 1798 it was written that Duro Vardžík came to Kysáč in 1773, but it is omitted that he was still underage at that time and it is not said that he had come with his father Michal, who died in $1792 .{ }^{49}$ That is why some authors wrongly stated that Duro Vardžík was the first Slovak to arrive in Kysáč in 1773.

Samuel Čelovský correctly states that the first Slovak to arrive in Kysác was in fact Michal Vardžík (1736-29 November 1812), ${ }^{50}$ but the date of M. Vardžík's death is misleading here. ${ }^{51}$ Michal Vardžík, the son of Ján and Ana Vardžík, died on 29 November 1792 when he was 56, from the exhaustion of his body (Cachexia). ${ }^{52}$ So, F. Jesenský could

\footnotetext{
${ }^{43}$ Obviously, this confusion is due to the term Valach, i. e. lingua valachica, under which the authors mainly imply the Romanian nationality, i.e. the Romanian language, neglecting the fact that at that time, these terms were also used for the members of other nationalities in the Balkans who were engaged in cattle breeding, mainly for the Serbs. However, it is stated here that in the neighboring settlements Zmajevo (Kér), Despotovo (Deszpot Sz. Ivan), and partly in Kucura (Kuczora) lived the Orthodox population (Shismatics) who spokek the Serbian language (lignua Illirica). It is obvious that the criteria for understanding nationalities and languages were not sufficiently differentiated.

${ }^{44}$ Gavrilović 1977: 177, 181.

${ }^{45}$ Borovsky I: 128; Borovsky II: 353.

${ }^{46}$ Jesenský 1773: 7.

${ }^{47}$ Maliak 1925: 42.

${ }^{48}$ Babiak 2015: 291.

${ }^{49}$ Jesensky 1773: 8.

${ }^{50}$ Čelovský 2013: 45.

${ }^{51}$ Obviously this is a printing error because in a former work the author gives the exact date of Michal Vardžík's death. (Čelovský 2010: 443)

${ }^{52}$ The first register of births, deaths and marriages in Kysáč was kept from January 1, 1787 to December 31, 1831
} 
not have known him because he came to Kysáč in 1794. That is why he wrote in the Chronicle that the first Slovak to arrive in Kysáč was "the father of Duro Vardžík." 53 Half a year after the death of her spouse Michal, his vidow Eva (born Malík) married Tomás Sabadoš on 17 June 1793. She died of old age when she was 70 years old on 20 November 1812. Čelovský states that Michal Vardžík came to Kysáč with his son Ján and his daughters Judita (1771) and Mária (1773). ${ }^{54}$

We did not find any information about Ján Vardžík in the record books in Báčsky Petrovec at the time when the evangelists from Kysáč made a branch of the Evangelical Parish in Petrovec, from 1783-1787, nor in the record books of the Evangelical Church in Kysáč, which were kept there since 1787.

However, there is a lot of information referring to the family of Michal Vardžík in the aforementioned record books in Báčsky Petrovec and Kysáč. Since he was the first Slovak to arrive to Kysáč, we are going to pay a little more attention to this family.

Adam, the son of Michal and Eva Vardžík, was born on 13 March 1785. His godfathers were Štefan and Zuzana Pap, who moved from Futog to Kysáč in 1772. This shows a strong bond of the first evangelists who came to Kysác in 1772-1773. After that, on 4 March 1784, the son of Michal Vardžík, two-year old Pavel, died. In the birth registry there is no information on his birth, because the data on the evangelists in Kysáč were not kept in the record books in Petrovec until 1783. After that, on 19 July 1789, Michal Vardžík, the son of Michal and Eva, was born and the godfathers again were Štefan and Zuzana Pap.

In order to have a broader picture of the family of Michal Vardžík, the first Slovak to arrive in Kysáč in 1773, here are some more data on his children. On 21 November 1791 his daughter Mária married Ján Cefer from Kysáč. His other daughter Judita married Ján Virág from Futog on 23 June 1794. After she had been widowed at the age of 35, she was remarried to Pavel Streda, a 42-year old widower from Novi Sad on 20 April 1806. On 17 November 1806 Michal's 19-year old son Adam married 16-year old Mária Selská from Kysáč. On 24 November 1808 his 19-year old son Michal married Zuzana Fad'oš from Kysáč. On the same day 19-year old Pavel Vardžík, son of his brother Duro/Juraj (whose wife was Judita Vozár), married 17-year old Mária Šranka.

Despite a lot of data found in the preserved register books, there are some questions, though, to which we do not have answers. We could not find any information on Ján, son of Michal Vardžík, who, according to S. Čelovský, came to Kysáč with his father in $1773 .{ }^{55}$ Likewise, there are no data either on the birth or on the wedding ceremony of Michal's son Duro, but there are data on the birth and death of his children in his marriage with Judita Vozár: on 8 January 1787 Pavel was born; on 29 January 1789 Ďuro was born and he died on 12 March that same year; on 12 January 1790 Judita was born and sh e died on 20 December that same year; on 3 August 1793 Eva was born and she died the next day; on 7 October 1794 Judita was born; on 16 April 1797 Ďuro was born; on 8 November 1800 Zuzana was born and she died on 7 January 1801; on 7 January 1802 Mária was born; on 9

\footnotetext{
and can be found in the Archives of the Slovak Evangelical Church in Kysáč

${ }^{53}$ Jesenský 1773: 7.

${ }^{54}$ Čelovský 2013: 45.

${ }^{55}$ Čelovský 2013: 45.
} 
March 1805 Zuzana was born. The example of Duro Vardžík's family, his son Michal, the first Slovak to arrive in Kysáč, shows that death rate among children was very high, especially among newborn babies: out of eight children four of them died in the first year of their life.

Jozef Maliak, referring to F. Jesenský's Chronicle of Kysáč, states that Count A. Hadik had moved from Futog, from the lower forest, to Kysác four Hungarian families, who had lived there in dugouts. ${ }^{56}$ Čelovský, too, refers to the Chronicle of F. Jesenský, and states that on the order of landowners, from Futog to Kysáč were transferred three Evangelical families in 1773 - Čižmadia, Német and Pap, who were brought to Kysáč by Count A. Hadik from Transdanubian Hungary, i.e. from Sent Lorinc and Mislan (Szent Lörinc, Miszla), Tolna County.

He further states that these families first lived in the dugouts near the Futog forest, where they watched over the bricks and tiles from the brick plant of Futog. ${ }^{57}$ There are several imprecisions and false claims, though. S. Čelovský does not cite the source of his claim that Count Hadik brought the four aforementioned families with him to Futog. The village of Sent Lorinc was in the Baranja County, west of Pečuj (Pécs), not in the Tolna County. Likewise, it is unknown where he came across the information about these three people watching over the arranged bricks and tiles belonging to the landlords of Futog.

In his Chronicle, F. Jesenský clearly states that Štefan Pap and his brother Duro Pap were noblemen. They first lived in the Lower Forest near Futog, in dugouts, but then Count Hadik, the landlord of the Futog ground estate, ordered them to move to Kysáć, because they lived near the place where their landlord planned to build a brick plant. ${ }^{58}$

Samuel Čelovský says that Count Hadik had the aforementioned four people transferred to Kysáč at the very time of the arrival of the first Slovaks in it, in accordance with the state practice of the time to settle the people of the same religion into the same village. ${ }^{59}$ With this we can only partially agree because the facts show that these four people came to Kysáč before Michal Vardžík. Namely, in the Urbarial Census of the inhabitants of Kysáč from 1772, three, according to Maliak, "Hungarian" ${ }^{60}$ families were recorded: Štefan Pap, Duro Pap and František Német under the ordinal numbers 103, 104 and 105, however, Michal Vardžík is not on the list. ${ }^{61}$ However, according to the Lexicon locorum Regni Hungariae populosorum anno 1773, no Hungarians, Slovaks or Evangelists lived in Kysác at that time. The majority of the population were Orthodox people who spoke the "Vlach" language. ${ }^{62}$ It is possible that Count Hadik had already had a plan to settle Kysác with a larger number of evangelical Slovaks. But, he first settled the aforementioned four

\footnotetext{
${ }^{56}$ Maliak 1925: 42.

${ }^{57}$ Čelovský 2013: 45.

58 „Aliquot familiae Hungaricae, nominatim Stephanus Pap, nobilis, Georgius Pap, prioris Frater, ibidem Nobilis, Franciscus Német, Joannes Czizsmadia quos Sua Excellentia Andreas Hadik, qua Dominii Futtak Terrestris Dominus a Sylva Futtakiensi inferiori, ubi in Subterraneis domibus, vulgo zemnica, dictis, non procul ab eo loco, ubi Dominium tegulas conficiendas curat, degebant, ad Kiszáts transire iussit” (Jesenský: 1773:7).

${ }^{59}$ Čelovský 2010: 448. In the urbarial census, as citizens of Kysac were recorded the families of František Német, Štefan and Ďuro Pap. So, they came before Michal Vardžík.

${ }^{60}$ Maliak 1925: 42

${ }^{61}$ OL, E szekció 156 - a. - Fasc. 158. - No. 024

${ }^{62}$ Lexicon locorum Regni Hungariae populosorum anno 1773..., Budapestini, 1920: 24.
} 
evangelical Hungarians, perhaps even magyarized Slovaks. Here we should point out that Count Hadik's family was evangelical and that only much later did they become Catholics. ${ }^{63}$

According to F. Jesenskýs Pamätnica ${ }^{64}$ the intensive arrival of Slovaks in Kysáč was carried out until the end of the $18^{\text {th }}$ century, during the whole quarter of a century, in the period from 1773 to 1798 . They arrived from 55 settlements, from the following counties: most families came from Novohrad, then from Hont, from Liptov, from the Nitra County, from Turec, from the Zvolen County, the Pest County, the Békés County, the Tolna County, as well as from Slovak settlements in Bačka: Petrovec, Hložany, Kulpín, Selenča. On the basis of his own research S. Čelovský claims that Kysáč was settled by the population from 89 different villages and from 19 counties. ${ }^{65}$

In 1779, a list of evangelical Slovaks in Kysáč was made on which there were 52 inhabitants/families who gave their donations for the construction of the Evangelical Church. ${ }^{66}$

The first wave of the arrival of Slovaks in Kysáč extended over ten years with the climax in 1776/1777. In this period came around 90 Slovak families, which was twice the number of the native Serbian families. ${ }^{67}$

On the basis of the names and surnames recorded in the second urbarial census (under the name Tabella Urbarialis Secundum Geometricam Efective Confectam Dimensionem Benigno Urbario Conformites elaborata Possesionis Kiszacs) from 1781, it can be assumed that in Kysáč there were 64 Serbian houses, 58 Slovak and 7 Hungarian ones. However, two surnames, on the basis of their Latin version, cannot be classified into any group. The number of family members was not recorded. ${ }^{68}$

The issuing of the Patent on Tolerance (1781) prompted the arrival of a new wave of migrants in 1783. The migration reached its climax in 1786, when as many as 74 families arrived in Kysáč. ${ }^{69}$ According to the notes of the commissar of the Bačka County Andrej Virág, in 1789 there were 919 Slovaks in Kysáč. They had their school which, at the same time, served as a place for prayer and a parish home. It was agreed that each resident would pay 1 forint and 30 kreuzers for the maintaining of the school and the parish. ${ }^{70}$

Since the area around Kysáč was very small, the lack of free land stopped the arrival of new Slovak migrants. ${ }^{71}$ The last large group of Slovaks, including 35 families, came into this settlement in 1790 . In the last decade of the $18^{\text {th }}$ century a smaller, symbolic number of Slovak families arrived to Kysáč. ${ }^{72}$

The Chronicle of F. Jesenský contains quite a lot of data on the social structure of Slovaks in Kysác at the end of the $18^{\text {th }}$ and at the beginning of the $19^{\text {th }}$ centuries. The first preserved census of Slovaks in Kysáč was made by priest F. Jesenský at the beginning of

\footnotetext{
${ }^{63}$ Đere 2014: 230.

${ }^{64}$ Čelovský 1996: 61.

${ }^{65}$ Čelovský 2013: 47.

${ }^{66}$ AV BBŽ, 1092/1780.

${ }^{67}$ Babiak 2013: 56.

${ }^{68}$ Miklovic 2013: 68.

${ }^{69}$ We do not know how many citizens of Kysáč there were in 1785, when they got a teacher. F. Jesenský claims that M. Slamay, the first evangelical priest in Kysáć, took the data away when he was transferred. (Jesenský 1773: 7)

${ }^{70}$ AV BBŽ no.167/1789; AV, BBŽ no. 123/1789; Jesenský 1773: 7.

${ }^{71}$ Čelovský 2013: 47

72 Babiak 2013: 56.
} 
1795, who also recorded the data into his Chronicle. At the time, this Evangelical parish had 1289 believers, 681 male and 608 female, of which 419 male and 371 female believers received confirmation. In the current year another 29 male and 15 female believers should have received confirmation. In children under the age of 12 who did not receive confirmation there were 223 boys and 222 girls. There were 279 married couples, 26 widowers and 20 widows. Of that, 175 families had their own houses and 68 families did not have them. The church community had 102 believers who lived on homesteads. ${ }^{73}$ The following similar censuses recorded the increase of the number of the inhabitants of this church community: in January 1798 there were 1317 Evangelists in Kysác and on the homesteads near Novi Sad another 113 Slovaks Evangelists. According to the list of the cannonical visitation performed by superintendent Martin Hamaliar on 15 September of the same year, there were 1332 Evangelists in Kysáč and on the homesteads near Novi Sad 128 Evangelists. In the following year, 1799, there were 1326 Evangelists in Kysáč, and on the homesteads near Novi Sad - 110; in 1800 - in Kysáč there were 1360 and on the homesteads near Novi Sad - 71; in 1801 - in Kysáč there were 1349 Evangelists, on the barren areas around Novi Sad - 71 Slovaks Evangelists. ${ }^{74}$ This slight decline in the number of the inhabitants in 1801 might be the consequence of increased mortality as well as increased migration. From 1794 on, Jesenský recorded precisely for each year the new immigrants and emigrants, always citing the places from which they were coming or to which they were going. In the first decade of the $19^{\text {th }}$ century the number of Slovaks in Kysác was slightly increased: in 1802 there were 192 househods in the village and 70 homeless families. There were 303 married couples, 18 widowers, 30 widows. Of the total number 824 received confirmation, 55 were going to receive it in the current year and there were 520 children under the age of 12 who received no confirmation. There were 1399 Slovaks Evangelists in the village and on the homesteads around Novi Sad another 81 .

The census from 1805 gives more details on Slovaks in Kysáč. There were 188 houses, including Teodor's mill, the mill of Andrej Pavlov and Pavel Filko, the evangelical school and the parochial home, the landowner's inn and a home for tramps. The whole land session was attended by 4 households, the $3 / 4$ of the session by 10 households, half a session -63 households, $1 / 4$ session -105 households. There were 81 subinquiline families. ${ }^{75}$ These facts give a rather unfavourable picture of the social and economic position of Slovaks in Kysáč. 321 married couples lived in 180 houses. The most numerous were the households who used $1 / 4$ of a session, those with $3 / 4$ or the whole session being very rare. On the homesteads around Novi Sad there were 113 Slovaks who belonged to the Kysác Evangelical community. They had 24 houses, but they worked and lived on homesteads. There were only 182 rural households in Kysáč, which meant that in one household there might have been two or three married couples, married sons or daughters who lived together with their parents. On average, one rural household possessed 0.37 land session, which was barely enough to survive taking into account that in one household there were sometimes

\footnotetext{
${ }^{73}$ Jesenský 1773: 7

${ }^{74}$ Ibid.

${ }^{75}$ Ibid. 18 .
} 
two or even three married couples, and families often had 3, 4 and more children. In the list there are no details about craftsmen, only two mills are mentioned. Obviously, a significant number of those who had not received the land to use were day labourers, male and female servants, but there are no details on how they provided for their families. Difficult social and economic circumstances for the citizens of Kysác did not attract new colonists.

At the beginning of the settlement of Slovaks in Kysáč colonists belonged to various social and economic categories. Peasant farmers made the majority of the population, but there were noblemen, too, as well as evangelical priests, teachers, later craftsmen, civil servants and others. The first nobelmen, in all likelihood, were the first Evangelists who moved from Futog to Kysác in 1772/1773: of the aforementioned four, two of them, brothers Štefan and Ďuro Pap, were noblemen. In the list of armalists of the Bačka County from 1791, two noblemen armalists were recorded in Kysáč: Štefan Pap and Pavel Hankuš. Duro Pap is not mentioned here. ${ }^{76}$ The Súdi family was, too, of noble origin, which was always highlighted in the first register of the Evangelical Church in Kysáč. Bačka County officially requested and obtained the confirmation from Hont County that the Súdi family was of noble origin. ${ }^{77}$ František Jesenský, the second in rank evangelical priest in Kysáč, was also of noble origin. He sent a petition to the assembly of the Turoc County to issue him a certificate that he was of noble origin, so that he might have proof of that in the Bačka County and nearby counties and use the noble title and all the privileges coming out of it. On June 13, 1796 Turoc County sent a letter to Bačka County certifying that the family Jesenský de Jeszen was indeed of noble origin. ${ }^{78}$ However, as it is often the case, there are black sheep in every flock. Unpleasant events and various disorders were not rare in Kysáč. For instance, the authorities of the Bač-Bodrog County sent a request in 1785 for catching robber Jovan/Ján Fábor who allegedly hid in Kysáč. ${ }^{79}$ After that, in 1793, a bandit from Kysáč Ján Kováč was caught with his accomplices in Debrecin, so the authorities asked from the Bač-Bodrog County information on them, which this county gave. ${ }^{80}$ Sometimes even soldiers who were settled in villages started riots. All kinds of disorders happened, even during the recruitment period. Thus, during a recruitment in Kysáč in 1804, a commander's assistant killed Jovan Obrovčanin, after which an investigation was conducted with the examination of the witnesses. ${ }^{81}$

At the end of the $18^{\text {th }}$ and the beginning of the $19^{\text {th }}$ century the largest part of the population in Kysáč were peasants, who were divided into several categories, depending on whether they owned a house and whether they got land to use from their landlords. The most numerous were the peasants (colons), who had their own houses and a certain area of land acquired for use. The basic unit for the allocation of land was a session. The whole

\footnotetext{
${ }^{76}$ AV BBŽ, 246/1791, 89-90 - the list of armalists of the Lower District of Bačka County.

${ }^{77}$ AV BBŽ, kut. 352, 25/1804; AV BBŽ, kut. 355, 27/1804.

${ }^{78}$ AV BBŽ, 170/1796 - the copy of a letter from Turoc County sent to Bač-Bodrog County. At the same time the same letter/testimony arrived to Bačka County and to Peter Jesenský, evangelical priest in Hložany, the son of Dávid, the son of Tobiáš, evidently a relative to F. Jesenský (AV BBŽ, 169/1796).

${ }^{78}$ AV BBŽ, kut. 139, 72/1785.

${ }^{79}$ AV BBŽ, kut. 139, 72/1785.

${ }^{80}$ AV BBŽ, kut. 265, 99/1793; AV BBŽ, kut. 266, 37/1793.

${ }^{81}$ AV BBŽ, kut. 355, 27/1804.
} 
session consisted of 54 acres outside the built-up areas (extravilan) and 1 acre around the house (intravilan). The peasants usually got the whole session from their landlords, 3/4 , a half or $1 / 4$ of a session, but rarely more than a session. Accordingly, they paid the rent/census and other obligations in kind and work annuity. The peasants who owned a house but had no land, or had less that a fourth of a session, were not considered to be true peasants and they belonged to the cathegory of tenants (inquilines). Subtenants (subinquilines) were those who had neither their own house nor land. Subinqilines were mostly day labourers or they worked as workers and servants on the estates/homesteads, farms around Novi Sad, homesteads belonging to the ground estates of Irmovo, Alpar, Dragovo, Bodonj. Some used to work as day labourers in vineyards in Srem, where there was work for day labourers during almost all year round. ${ }^{82}$ The vicinity of the free royal city of Novi Sad offered the possibility for day labourers, servants, maids and physical workers to look for and find some job. Some made their living as hired coachmen who transported merchandise for salesmen wherever it was needed, very often, as we have mentioned, as far as Pest.

Disputes between the peasants and landlords or between the administration and officials were not rare at the time. It is a well known fact that the family Čarnojević, the owner of the ground estate of Futog (1744-1769), had many disputes with its subjects. The reasons for the disputes were various, but at their core was always the intention of the landlord to get from his subjects as many taxes and obligations as possible.

In 1771, the citizens of Kysáč sent an appeal to the Bač-Bodrog County against a former mediator of the Čarnojević ground estate of Futog complaining about the nonimplementation of the urbar. ${ }^{83}$ After that, in 1774, an accusation was raised against an inspector of the Latinovic ground estate of Futog because of the overburdening of the peasants and urbarial disorders. ${ }^{84}$ In some cases, the state, i.e. its authorities, had to defend their citizens, admitting that they were often overburdened, much more than it was expected by the urbarial acts. Thus, for instance, in 1782, the Regency Council returned the urbarial table to the ground estate landlords of Futog for a revision, with a note that a 1000 acres more were shown in it, ${ }^{85}$ which meant that the citizens paid for a bigger land area than they had really been given to use. We do not know how this revision was completed. Obviously, the ground estate landlords of Futog tried to settle as many Slovaks as possible in Kysác and at the same time to be very frugal in alloting the land. Due to that, the citizens were often forced to take on lease of the land that had not yet been alloted. The citizens of Kysác in such a way took on lease 11 free sessions (1 session consisting of 55 Hungarian acres) from the ground estate of Futog. ${ }^{86}$

In the 80 's the ground estate of Futog signed each year with every municipality an urbar which precisely previewed all the obligations of the subjects. Thus, the representatives of the municipality of Kysác signed the statements in three consecutive years - 1784, 1785 and 1786 - that the municipality received the urbar and that they had no remarks against the

\footnotetext{
82 Čelovský 2013: 47.

${ }^{83}$ AV, BBŽ, 1141-1142/1771; AV, BBŽ, 1143-1150/1771.

${ }^{84} \mathrm{AV}, \mathrm{BBŽ,}, 362 / 1774$.

${ }^{85}$ AV BBŽ 345/1782.

${ }^{86}$ AV BBŽ, 588/1783 - the contract of the citizens of Kysáč with Futog landowners on land lease of 11 free sessions.
} 
landlords and their officers. ${ }^{87}$ However, they were still having a dispute with a former landlord Čarnojević, who owed them 1132 forints and 30 kreuzers for the cattle he had bought. ${ }^{88}$

Regardless of very unfavourable social and economic circumstances, the Slovak Evangelists in Kysáč, already in the first years since the beginning of settlement, found forces and ways to organize themselves as an ethnic and religious community and to collect money, by their own engagement and renunciation, for the first fund for establishing their own school and a church. Thus, already in 1779 a fund was created for building an Evangelical Church in Kysáč, when 52 families collected 206 forints and 54 kreuzers. ${ }^{89}$

The arrival of such a large number of Slovaks in Kysáč on the basis of the Patent of Tolerance ${ }^{90}$ enabled in 1785 the creation of the conditions for establishing a school and engaging the first teacher. S. Čelovský emphasizes that the Patent of Tolerance had a great impact on the national and cultural life, on the development of the evangelical national education because it enabled the communities with at least 100 evangelical families ${ }^{91}$ and 500 inhabitants to establish a school and get a teacher. ${ }^{92}$ The Slovak citizens of Kysác belong among those Slovak native people who first established a school and only in the following years called a priest and started building a church. ${ }^{93}$

\section{SOURCES:}

The Archives of Vojvodina Novi Sad, Fund: Bač-Bodrog County (AV BBŽ)

The Archives of the Slovak Evangelical Church of the Augsburg Religion in Kysác (SECAVK/SECARK)

The Archives of the Slovak Evangelical Church of the Augsburg Religion in Báčsky Petrovec (SECAVBP/SECARBP)

Országos Leveltár, Budapest (OL) - The State Archives of Hungary, Budapest

\footnotetext{
${ }^{87}$ AV BBŽ, 725/ 1784; AV BBŽ, kutl 147, 176/1785; AV BBŽ, kut. 147, 160/1786.

${ }^{88}$ AV BBŽ, 137/1913/1785; AV BBŽ 971/976/1785.

${ }^{89}$ AV BBŽ, 286a/1778; AV BBŽ, 1092/1780.

${ }^{90}$ The Patent of Tolerance of the emperor Josef II is an enlightenment church reform issued in 1781. 16 items of the patent precisely determine the religious freedom of non-catholics - evangelists of the Augsburg and Calvinist religion, as well as Orthodox Chrisitans, who, if only formally, were equated with the Catholics. Among the important determinants of the Patent was the possibility of building their own church, school, parish, performing church rites in order to be able to publicly confess their faith (Pavlík, 2. diel, 1985: 444)

${ }^{91}$ The paragraph 2 of the Patent of Tolerance refers to where and under which conditions Evangelists can establish their church municipality and build a church, parish and school. The condition was that there would be 100 houses in which the Evangelists would live Evangelist.

http://ecav.sk/?p=info/INFHistória/udalosti/tolerancny_patent_-_230_vyrocie

Source: Tranovský evanjelický kalendár na rok 2011. Miloslav Gdovin | 25.10.2011

${ }_{92}$ Čelovský 1996: 61

${ }^{93}$ Ibid. 2013: 74
} 


\section{REFERENCES:}

Ambruš, M., Hlásnik, P. and Unc, B. (eds.), Dolnozemskí Slováci hranice určenia, Nădlac: Vydavatel'stvo Ivan Krasko, 2013.

Auerhan, J. Čechoslováci v Jugoslavii, v Rumunsku, v Mad’arsku a v Bulharsku, Praha: Melantrich, 1921.

Babiak, J. 'Príchod Slovákov do Kysáča', in: Za slnkom napoludnie. Stahovanie Slovákov na Dolnú zem, a ešte južnejšie, Báčsky Petrovec: Asociácia slovenských pedagógov, 2015b, 289-310.

. 'Začiatky slovenského Kysáča (prvých 25 rokov Slovákov v tejto osade)', in: V. Valentík, (ed.). Kysáč 1773-2013: zborník prác, Báčsky Petrovec: Slovenské vydavatel’ské centrum, Matica slovenská v Srbsku; Kysáč: Rada Miestneho spoločenstva, 2013.

.Za slnkom napoludnie. Stahovanie Slovákov na Dolnú zem, a ešte južnejšie, Báčsky Petrovec: Asociácia slovenských pedagógov, 2015a.

Babiak, J. at al. Atlas l'udovej kultúry Slovákov v Juhoslávii / Atlas narodne kulture Slovaka u Jugoslaviji, Báčsky Petrovec: Matica slovenská v Juhoslávii, 2002.

Bartoš, V. at al. Slováci v Erdevíku 1860-1907-1997, Erdevík: Slovenský kultúrno-osvetový spolok; Báčsky Petrovec : Kultúra, 2001.

Benková, V. Z dávneho Petrovca, Novi Sad: Hlas ludu, 1998.

Bielik, F., Sirácky, J. and Baláž, C. (eds.), Zahraniční Slováci a národné kultúrne dedičstvo, Martin: MS, 1984.

Boldocký S. (ed.), Petrovec 1745-1995, Báčsky Petrovec: Zhromaždenie obce, 1995.

Borovszky, S., Bacs-Bodrog vármegye, I, Budapest, 1909.

Boškov, S. Gavrilović, V. (eds.), Vojvođanski prostor u kontekstu evropske istorije. knj. 2, Novi Sad: Filozofski fakultet, 2014.

Botík, J. 'K počiatkom záujmu o historický a etnický vývin dolnozemských Slovákov', Etnologické rozpravy, 15/2, 2008, 52-62.

. 'Procesy akulturácie u dolnozemských Slovákov', Národopis Slovákovv Mad'arsku, 7, 1988, $117-124$.

. 'Slovenské dolnozemské komunity a ich elita do roku 1918', Acta historica Neosoliensia 12, 2009, 81-99.

. 'Zvláštnosti kultúry zahraničných Slovákov', Studia Academica Slovaca, 23, 1994, 21-30.

. 'L'udová kultúra dolnozemských Slovákov a ich etnický vývin', in: J. Sirácky Slováci vo svete

1. Martin : Vydavatel'stvo Matice slovenskej, 1980, 231-275.

. Donozemskí Slováci, Nadlak: Ivan Krasko, 2011.

. Etnická história Slovenska. K problematike etnicity, etnickej identity, multietnického Slovenska a zahraničných Slovákov, Bratislava: Lúč, 2007.

. Tam zložili aj svoje kosti (Kultúrnohistorické hodnoty náhrobných pomníkov zahraničných Slovákov), Bratislava: Lúč, 1999.

Bukurov, B. and Chrt’an, P. Obec Báčsky Petrovec, Báčsky Petrovec: Zhromaždenie obce, 1979.

Cicka, J. Kovačica 1802-2002. Zborník prác pri dvestoročnici mesta, Kovačica: Miestne spoločenstvo, 2002.

Csánki, D. Magyarorszák történelmi földrajza a Hunyadiak korábon, II, Budapest,1894.

Čáni, L. (ed.), Slováci v Juhoslávii, Bratislava: DZS, 2001.

Čaplovič, J. Dejiny slovenského evanjelického a. v. cirkevného sboru v Kovačici. Kovačica: SEAVCS, 1928.

Čelovský, S. 'Peštbudínske vedomosti ako prameň informácií o národnokultúrnom a národnopolitickom živote Slovákov vo Vojvodine', Zborník Spolku vojvodinských slovakistov, 4, 1982, 75-100. 
Čelovský, S. 'Prehl'ad publicistickej a literárnej tvorby Félixa Kutlíka v rokoch 1867-1877', Zborník Spolku vojvodinských slovakistov, 2, 1980a, 79-116.

. 'Bibliografia prác Félixa Kutlíka z rokov 1867-1877', Zborník Spolku vojvodinských slovakistov, 2, 1980b, 117-123.

. 'Slovenské noviny (1849-1861) ako prameň informácií o živote Slovákov vo Vojvodine', Zborník Spolku vojvodinských slovakistov, 10, 1980c, 5-42.

. 'Slovenská l'udová škola v Kulpíne v období feudalizmu (1789-1848)', in: Pamätnica 17891989, 200 rokov Základnej školy Jána Amosa Komenského v Kulpíne, Báčsky Petrovec: Kultúra, 1996, 56-124.

. 'Najstaršia epigrafická pamiatka Slovákov v Srbsku', in: Z kultúrnych dejín Slovákov vo Vojvodine. Báčsky Petrovec: MOMS, 2010b, 326-348.

. 'Podiel osadníkov zo slovenských obcí v Mad’arsku pri osídl’ovaní Kysáča v Báčke od roku

1773', in: V. Valentík (ed.), Kysáč 1773-2013: zborník prác, Báčsky Petrovec: Slovenské vydavatel'ské centrum, Matica slovenská v Srbsku; Kysáč: Rada Miestneho spoločenstva, 2013. . 'Podiel osadníkov zo slovenských obcí v Mad’arsku pri osídl'ovaní Kysáča v Báčke od roku 1773', in: Z kultúrnych dejín Slovákov vo Vojvodine. Báčsky Petrovec: MOMS, 2010c, 442-457. . Pamätnica 1789-1989, 200 rokov Základnej školy Jána Amosa Komenského v Kulpíne, Báčsky Petrovec: Kultúra, 1996. . Z kultúrnych dejín Slovákov vo Vojvodine, Báčsky Petrovec: MOMS, 2010a.

Čukan, J. (ed.), Bolovce. Kultúrne tradície Slovákovv Srieme, Báčsky Petrovec - Nitra: SVC, 2011. . (ed.), Pivnica. Kultúrne tradície Slovákov v Báčke. Báčsky Petrovec, Nitra: SVC, 2010. . (ed.), Silbaš. Kultúrne tradicie Slovákov v Báčke, Báčsky Petrovec, Nitra: SVC, 2013. . (ed.), Sol’any. Kultúrne tradicie Slovákov v Slavónii, Nitra: UKF - Sol'any Matica slovenská, 2014.

Dudok, M. at al. 250 rokov života Slovákov vo Vojvodine, Beograd: Zavod za udžbenike i nastavna sredstva, Novi Sad: Spolok vojvodinských slovakistov, 1996.

Đere, Z. 'Vojskovođa Marije Terezije: Grof Andraš Hadik od Futoga', in: Gavrilović, V., Boškov, S. (eds.), Vojvođanski prostor u kontekstu evropske istorije. Novi Sad: Filozofski fakultet, 2014, 229-242. (Serbian Cyrillic)

Fekete, S. et al. Hložany 1756-198, Báčsky Petrovec: Kultúra, 1986. . Hložany 2. Báčsky Petrovec: Kultúra, 1998.

Gašparovský, J. Selenča 1785-1998: Zborník prác, Selenča: Slovan, Báčsky Petrovec:

Gavrilović, S. Rusini u Bačkoj i Sremu od sredine XVIII do sredine XIX veka, Godišnjak Društva istoričara Vojvodine, Novi Sad, 1977, 153-215.

Hučoková-Klinková, M. at al. Zachráňme od zabudnutia: (Aradáč 1786-2006), Báčsky Petrovec: Kultúra, 2005.

Jakšić, I. Iz popisa stanovništva Ugarske početkom XVIII veka, Novi Sad. (Serbian Cyrillic)

Jančovic, J. Vyorali hlboké dolnozemské brázdy, Nadlak: Vydavatel'stvo Ivan Krasko, 2009. . Z kolisky na Dolnú zem, Martin: MS, 2004.

Jančovic, J. Za chlebom na Dolnú zem (Úteky, stahovanie a osadenie Slovákov z Novohradu počas feudalizmu), Pôtor: Obecný úrad, 2003.

Jesenský, F. Pamätnica historických zápisov, staršich a novšich, o povstani a d'alšom zvel'ad'ovani cirkvi, počnúc od r. 1773, Archív SECAV v Kysáči.

Jovankovič, S. Z minulosti vojvodinských Slovákov. Štúdie, články, portréty, prednášky a spomienky, Nadlak: Vydavatel'stvo Ivan Krasko, 2014.

Kišgeci, J. (ed.), Petrovská dedina (výpisy z petrovských kroník), Novi Sad: Hlas l’udu, 1997.

Kmet', J. 'Ján Stehlo a jeho Petrovská kronika', Zbornik Spolku vojvodinských slovakistov, 3, 1981, $39-58$ 
Kmet', J. Dolnozemské obrysy slovenskej sebaúcty (1990-1993), Bratislava: Spolok Slovákov z Juhoslávie, 1994.

Kmet', M. 'Vlastivedná a osvetová činnost' učitel’ov v slovenských enklávach na Dolnej zemi v 19. storočí', in: Nám i budoucím (muzejní, osvětová a vlastivědná činnost učitelů). Přerov: Muzeum J. A. Komenského, 2006, 234-247.

. 'Zo zápiskov kňaza v slovenskej osade v Srieme', in: Na prahu Modernej doby. Pramene k dejinám Slovenska a Slovákov IX, Bratislava: LIC, 2008, 318-320.

. Historiografia dolnozemských Slovákov v 19. storočí, 1. vyd., Békéscsaba: Výskumný ústav Slovákov v Mad'arsku, 2010a.

. Historiografia dolnozemských Slovákov v 19. storoči, 2. vyd., Nadlak: Vydavatel'stvo Ivan Krasko, 2010b. . Krátke dejiny dolnozemských Slovákov, Nadlak: Vydavatel'stvo Ivan Krasko, 2012.

Koleny, E. 'Banátski Slováci', Slovenské pohl'ady, 12, 1892, 462-470.

Kotváš, O. et al. Padina 1806-1996: zborník prác, Padina: MOMS, 1996.

Krajčovič, M. 'Srbsko-slovenské vzt'ahy v revolúcii 1848-1849', Zbornik Spolku vojvodinských slovakistov, 16-18, 1994-1997, 129-136. Kultúra, 1998.

Kutlík, F. 'Juraj Rybay', Slovenské pohlady, 5, 1887, 19-23.

. 'Kulpínska kronika Félixa Kutlíka z rokov 1876-1890’ (ed. Samuel Čelovský), Zborník Spolku vojvodinských slovakistov, 3, 1981, 89-134.

. Báč-sriemski Slováci (ed. J. Babiak), Kulpín: MOMS, 1998.

. Báč-Sriemski Slováci, Nemecká Palánka: Jozef Krištofek, 1888.

Lexicon locorum Regni Hungariae populosorum anno 1773 officiose confectum. Budapestini, 1920.

Lilge, K. Stará Pazova (monografia). Myjava: Daniel Pažický, 1932.

Listmajer, M. Osada Jánošík z môjho uhla 1810-2010, Báčsky Petrovec: SVC, 2010.

Lomiansky, P. 'Orgány, obce, ich rozvoj a pôsobenie v povojnovom období' in: S. Boldocký (ed.), Petrovec, Báčsky Petrovec: Zhromaždenie obce Báčsky Petrovec, 1995.

Maliak, J. 'Nazaréni - „Verící“', Cirkevné listy, 3/1, 1889, 7-10. . 'Kysáć', in: S. Štarke (ed.), Národný kalendár, Petrovec: Kníhtlačiareň úč. spol., 1925, 41-75. . 'Príhody prvých slovenských prist’ahovalcov južnej Báčke', in: Národný kalendár, Petrovec: Kníhtlačiareň úč. spol., 1921,113-116. . 'Ťažký život prvých osadníkov Petrovca', in: Národný kalendár, Petrovec: Kníhtlačiareň úč. spol., 1939.

. Daniel Kolényi a jeho doba, Petrovec: Kníhtlačiareň úč. spol., 1925. . Slovenské osadnictvo v Srieme, Praha: Zvláštní otisk z revue Naše Slovensko, 1908.

Matúch, P. (ed.), Lug. Dedinka v údolí, Stará Pazova: GKP SavPO, 2008.

Miklovic, J. (ed.), Ecclesiastica tabula coetus aug. Conf. Sacri Vetero Pasoviensis in Sirmio volumen VI. historia nec non oeconomia Ecclesia ab anno 1807-1825 alebo Jesenského kronika, Nadlak - Bratislava: Ivan Krasko - ESA, 2006.

Miklovic, J. 'Urbariálny súpis Kysáča z roku 1781’, in: V. Valentík, (ed.). Kysáč 1773-2013: zborník prác, Báčsky Petrovec: SVC, MS v Srbsku; Kysáč: Rada MS, 2013.

Miklovic, J. Stará Pazova 1769-1794. Bratislava - Nadlak: ESA - Ivan Krasko, 2002.

Mráz, A. Rozhovory o juhoslovanských Slovákoch, Bratislava: Pravda, 1948. . Rozhovory o vojvodinských Slovákoch, Báčsky Petrovec: Kultúra, 2004.

Ormis, J. ‘Jozef Maliak', Tranovský evanjelický kalendár na obyčajný rok 1946, 46, 126-129. . Kultúrne snahy Slovákov v Juhoslávii, Petrovec: Kníhtlačiareň úč. spol., 1935.

Pavlík, O. (ed.), Pedagogická encyklopédia Slovenska 1 a 2, Bratislava: Veda, 1985.

Petráš, J. Slováci v Aradáči. Aradáč: MOMS, Báčsky Petrovec: Kultúra, 1996. 
Ramač, J. 'Z minulosti Kysáča do roku 1773', in: V. Valentík, (ed.), Kysáč 1773-2013: zborník prác, Báčsky Petrovec: Slovenské vydavatel'ské centrum, Matica slovenská v Srbsku; Kysáč: Rada Miestneho spoločenstva, 2013.

. 'Prilog proučavanju urbarske regulacije u Bačkoj 1770. godine - odgovori na devet pitanja', Istraživanja, 15, 2010, 133-166. (Serbian Cyrillic)

Seberíny, J. ‘Ďalší vlastný životopis superintendenta Jána Seberényho', Slovenské pohl’ady, 27, 1907, $26-35$.

. 'Obraz našich kultúrnych pomerov s konca XVIII. stoletia', Slovenské pohl'ady, 26, 1906, 664-677.

Sečanski, Ž. Popisi stanovništva Bačke tokom osamnaestog veka (Građa za istoriju naselja i stanovništva), Beograd, 1952. (Serbian Cyrillic)

Sirácki, J. Mesto i značaj jugoslovenskih Slovaka u istoriji čehoslovačko-jugoslovenskih odnosa, Zbornik Matice srpske za društvene nauke, 48, Novi Sad, 1967, 40-52. (Serbian Cyrillic)

. Slovaci u Jugoslaviji: Prilog istoriji naseljavanja, Zbornik Matice srpske za društvene nauke, 44, 1966, 5-22. (Serbian Cyrillic)

. 'Hložany (Z dejín Slovákov vo Vojvodine)', Slováci v zahraničí, 9, 1983, 92-114.

. 'K vzniku a vývoju slovenského osídlenia na Dolnej zemi v 18. storočí', Historický časopis $X I, 3,1963 \mathrm{a}$.

. 'St'ahovanie Slovákov na Dolnú zem v 18. a 19. storočí', Slovenský národopis XI, 2/3, 1963b.

. 'Prehl'ad osídlenia', in: R. Bednárik (ed.), Slováci v Juhoslávii, Bratislava: SAV, 1966 a.

. 'Slováci vo Vojvodine ako historicko-etnografický fenomén', in: D. Dudok (ed.), Tradičná kultúra Slovákov vo Vojvodine, Novi Sad: Obzor, 1974, 11-23.

. Dlhé hl'adanie domova. 2. vyd., Martin: MS, 2002.

. Dlhé hladanie domova.1.vyd., Martin: MS, 1985.

. Stahovanie Slovákov na Dolnú zem v 18. a 19. storočí, Bratislava: Veda, $1966 \mathrm{~b}$.

Sirácky, J. at al. Slováci vo svete 1, Martin: MS, 1980.

Stupavský, S. at al. Slováci v Š́de: 1810-2010, Báčsky Petrovec: MS v Srbsku, 2010.

Svetoň, J. Slováci v európskom zahraničí, Bratislava: Slovenská akadémia vied a umení, 1943.

Šišmiš, M: 'Rodina Mičátkovcov a slovenská kultúra', Čabiansky kalendár na rok 1995, 33, 40-43.

Tomanová - Makanová, A. (ed.), 'Medzinárodná konferencia Slováci a Srbi - história a súčasnost', Novi Sad: NRSNM, 2014.

Turčan, J. at al. Stará Pazova 1770-1970, Novi Sad: Obzor, 1972.

Turčan, P. 'Kysáč', in: A. Vereš (ed.), Slovenská evanjelická krest'anská cirkev a. v. v Královstve juhoslovanskom v slove a obrazoch, Petrovec: Kníhtlačiarne úč. spol., 1930.

Valentík, V. (ed.), Selenča 1758-2008. Selenča: Združenie pre zachovanie kultúry, tradicií a umenia, Báčsky Petrovec: SVC, 2008.

Valentík, V. (ed.), Kysáč 1773-2013: zborník prác, Báčsky Petrovec: SVC, Matica slovenská v Srbsku; Kysáč: Rada Miestneho spoločenstva, 2013.

Vereš, A. (ed.), Slovenská evanjelická krestanská cirkev a. v. v Královstve juhoslovanskom v slove a obrazoch, Petrovec: Kníhtlačiarne úč. spol., 1930. 


\author{
ЈАНКО РАМАЧ \\ ДАНИЕЛА МАРЧОК \\ Универзитет у Новом Саду \\ Филозофски факултет \\ Одсек за русинистику \\ Одсек за словакистику
}

\title{
ДОСЕЉАВАЊЕ СЛОВАКА У КИСАЧ \\ (ОД 70-ТИХ ГОДИНА ХVIII ДО ПОЧЕТКА ХІХ ВЕКА)
}

\begin{abstract}
Резиме
Први словачки колонисти долазе у поједина насеља Футошког властелинства од средине 40-их година XVIII века. Први Словаци евангелици долазе у Кисач 1773. године. Наше истраживање је усмерено на почетак и прве деценије досељавања Словака у ово насеље. Циљ истраживања јесте да се на основу изворне грађе, првенствено Хронике кисачке евангелистичке цркве (1773) Франтишека Јесенског и грађе из Архива Војводине, која је била веома мало коришћена у досадашњим истраживањима, матичних књига из архива евангелистичких цркава у Бачком Петровцу и Кисачу, као и постојеће литературе, сагледа почетак, ток и основне социјално-економске прилике у време досељавања Словака у Кисач од 70-их година XVIII до почетка XIX века.
\end{abstract}

Кључне речи: „Доња земља”, досељавање Словака у Бачку, Футошко властелинство, Кисач, евангелици. 